\title{
CHANGES IN SOIL ORGANIC MATTER, ENZYMATIC ACTIVITIES AND HEAVY METAL AVAILABILITY INDUCED BY APPLICATION OF ORGANIC RESIDUES
}

\author{
P. Burgos, E. Madejón and F. Cabrera
}

Instituto de Recursos Naturales y Agrobiología (IRNAS) (CSIC)

Avenida Reina Mercedes, 10, P.O. Box 1052, 41080-Sevilla, Spain

A 3-year field experiment on a sandy soil supporting a strawberry crop was carried out to study the effects of the application of three organic residues (AC, olive mill wastewater sludge compost; MWC, municipal solid waste compost; and PW, paper mill waste) on organic matter content, enzymatic activities, and available heavy metals. Significant increases in organic carbon content (total organic carbon (TOC), total extractable carbon (TEC) and humic acid carbon (HAC)) were observed in soils, depending on the nature of organic amendments. The application of the organic residues also caused significant increases in dehydrogenase, phosphatase, B-glucosidase, urease and BAA-protease activities. This favourable effect on soil biological activity was more noticeable in $\mathrm{MWC}$ and $\mathrm{PW}$ treatments. Significant positive correlation $(p<0.01)$ between enzymatic activities and total organic carbon was found for all treatments. Available heavy metal contents increased slightly in the soils treated with MWC and PW but did not affect negatively soil enzymatic activities. A discriminant analysis generated two functions (F1 and F2) based on linear contributions of the variables (TOC, TEC, HAC, DHase, Phosp, $\beta$-glu, Ure, and BAA). F1 is correlated with DH-ase, TOC and BAA and separates treatments $\mathrm{C}$ and $\mathrm{AC}$ from $\mathrm{PW}$ and MWC. F1 underlines the effect of the higher doses of organic matter applied with MWC and PW. F2 is correlated with humic substances (TEC and $\mathrm{HAC}$ ), and $\beta$-glu separates treatments $\mathrm{C}$ and $\mathrm{PW}$ from $\mathrm{AC}$ and MWC. This function shows the difference of the effect of composted (AC and $M W C$ ) and fresh residues (PW) on soil properties. Results showed that the application of organic residues to a sandy soil improves its agronomic quality by increasing soil organic matter and enhancing soil enzyme activities.

\section{INTRODUCTION}

The pressures to sustain modern agricultural systems cause a progressive degradation of soil structure and a continued depletion of soil fertility level as a result of organic matter reduction [1]. The strawberry crop has great socio-economic importance in the Comarca Costa de Huelva (SW Spain), in which sandy soils with a very low organic matter content prevail. Intensive agricultural practices reduce the fertility of these soils. Consequently, these soils need organic matter application to improve and maintain their agronomic quality.

The use of organic residues as a source of organic matter is a common practice to improve physical, chemical and biochemical soil properties; their effect on soil can be observed for a long period after their application [2-7]. 
Soil enzymatic activities are important biochemical properties in the evaluation of soil fertility because many soil enzymes are involved in the cycle of nutrients [8]. The importance of soil enzymes lies on their participation in the processes involved in organic matter turnover [9]. Enzymatic activities are considered as important markers of soil regeneration through manuring practices [4] because they might indicate the potential soil fertility $[1,9]$.

On the other hand, the application of organic residues to soil could be one of the most useful and ecological approaches to solve two problems: wastes disposal and soil organic matter reduction. However, the use of certain organic residues can imply some hazards derived from their contents of heavy metals. Successive application of these residues can cause an accumulation of heavy metals in soil. Heavy metals content is a limiting factor for the continual and generalized agronomic utilization of some organic residues. A continuous monitoring of the concentration and availability of heavy metals in soil seems to be a judicious and necessary practice when organic residues rich in heavy metals are used.

This paper deals with the effect of the application as amendment of three organic residues to a sandy soil, over three successive applications on i) the content of organic matter, ii) the contents of available heavy metals ( $\mathrm{Fe}, \mathrm{Mn}, \mathrm{Cu}, \mathrm{Zn}, \mathrm{Cd}, \mathrm{Co}, \mathrm{Ni}$ and $\mathrm{Pb}$ ) and iii) the activities of five selected enzymes (dehydrogenase, phosphatase, B-glucosidase, BAA-protease and urease).

\section{MATERIALS AND METHODS}

\subsection{Soil and organic materiais}

The soil, a Typic Endoaquent [10], is a very representative soil of the "Comarca Costa de Huelva" (SW Spain), in which sandy soils prevail. The most relevant characteristics of the soil at the beginning of the experiment are in Table 1.

\section{Table 1}

Some soil characteristics at the beginning of the experiment

\begin{tabular}{llll}
\hline pH $(\mathrm{sat} . \mathrm{p})$ & 6.1 & Available-P $\left(\mathrm{mg} \mathrm{kg}^{-1}\right)$ & 22.8 \\
$\mathrm{EC}(1: 5)\left(\mathrm{dS} \mathrm{m}^{-1}\right)$ & 0.03 & Available-K $\left(\mathrm{mg} \mathrm{kg}^{-1}\right)$ & 116 \\
$\mathrm{CaCO} 3\left(\mathrm{~g} \mathrm{~kg}^{-1}\right)$ & $<2.00$ & Sand $\left(\mathrm{g} \mathrm{kg}^{-1}\right)$ & 808 \\
$\mathrm{TOC}\left(\mathrm{g} \mathrm{kg}^{-1}\right)$ & 3.6 & Silt $\left(\mathrm{g} \mathrm{kg}^{-1}\right)$ & 36 \\
Kjeldahl- $\mathrm{N}\left(\mathrm{g} \mathrm{kg}^{-1}\right)$ & 0.3 & Clay $\left(\mathrm{g} \mathrm{kg}^{-1}\right)$ & 156 \\
\hline
\end{tabular}

EC: Electrical conductivity.

Three organic materials from different origins were used in the experiment: i) an agricultural compost, made by olive mill wastewater sludge mixed with different agricultural wastes (AC), ii) a municipal solid waste compost (MWC) from the city refuse treatment plant of Villarrasa (Huelva, SW Spain) and iii) a paper mill waste (PW), produced by the paper industry of San Juan del Puerto (Huelva SW, Spain). Table 2 shows the most relevant characteristics of these three materials.

\subsection{Field study}

The experimental field consisted of thirty-two $45 \mathrm{~m}^{2}$ plots cropped with strawberries (Fragaria ananassa, cv. Camarosa). The plots were amended with the organic residues before planting. The following doses were annually applied for three years: treatment $\mathrm{AC}, 10000 \mathrm{~kg}$ $\mathrm{ha}^{-1}$; treatment MWC, $48000 \mathrm{~kg} \mathrm{ha}^{-1}$; and treatment $\mathrm{PW}, 48000 \mathrm{~kg} \mathrm{ha}^{-1}$. The organic residues 
were incorporated into the first $0-20 \mathrm{~cm}$ of soil by ploughing. A treatment $\mathrm{C}$, without organic amendment, was used as control for comparison. In the first two years, plots MWC and PW also received 110 and $220 \mathrm{~kg} \mathrm{ha}^{-1}$ of urea $(46 \% \mathrm{~N})$, respectively, to avoid $\mathrm{N}$-immobilization because of the high $\mathrm{C} / \mathrm{N}$ of these materials (Table 2). All plots also received the normal mineral fertigation used by the farmers in the area. The experiment was carried out in a completely randomized design with eight replications per treatment.

Table 2

Some chemical and biochemical characteristics of the organic materials

\begin{tabular}{|c|c|c|c|c|c|c|}
\hline & $\mathrm{AC}^{\mathrm{a}}$ & $S^{b}$ & $\mathrm{MWC}^{\mathrm{C}}$ & $\mathrm{SD}^{\mathrm{b}}$ & $\mathrm{PW}^{\mathrm{d}}$ & $\mathrm{SD}^{6}$ \\
\hline Moisture $\left(\mathrm{g} \mathrm{kg}^{-1}\right)$ & 198 & 13.0 & 368 & 9.88 & 769 & 0.82 \\
\hline TOC $\left(\mathrm{g} \mathrm{kg}^{-1}\right)$ & 152 & 9.47 & 268 & 19.8 & 260 & 11.5 \\
\hline Kjeldahl-N $\left(\mathrm{g} \mathrm{kg}^{-1}\right)$ & 9.94 & 0.56 & 12.6 & 0.66 & 2.74 & 0.62 \\
\hline $\mathrm{C} / \mathrm{N}$ & 15.3 & - & 21.3 & - & 94.9 & - \\
\hline $\mathrm{Fe}\left(\mathrm{mg} \mathrm{kg}^{-1}\right)$ & 12669 & 231 & 7616 & 332 & 3268 & 1134 \\
\hline $\mathrm{Mn}\left(\mathrm{mg} \mathrm{kg}{ }^{-1}\right)$ & 286 & 3.01 & 156 & 58.2 & 3734 & 1016 \\
\hline $\mathrm{Cu}\left(\mathrm{mg} \mathrm{kg}^{-1}\right)$ & 63.5 & 2.52 & 168 & 13.6 & 1472 & 480 \\
\hline $\mathrm{Zn}\left(\mathrm{mg} \mathrm{kg}^{-1}\right)$ & 61.4 & 1.82 & 366 & 63.2 & 1963 & 336 \\
\hline $\mathrm{Cd}\left(\mathrm{mg} \mathrm{kg}^{-1}\right)$ & 0.14 & 0.03 & 0.55 & 0.03 & 7.98 & 2.65 \\
\hline $\mathrm{Co}\left(\mathrm{mg} \mathrm{kg}^{-1}\right)$ & 7.82 & 0.46 & 3.23 & 0.14 & 146 & 50.4 \\
\hline $\mathrm{Ni}\left(\mathrm{mg} \mathrm{kg}^{-1}\right)$ & 71.8 & 2.77 & 60.9 & 17.2 & 91.8 & 11.6 \\
\hline $\mathrm{Pb}\left(\mathrm{mg} \mathrm{kg}^{-1}\right)$ & 11.3 & 0.48 & 188 & 25.8 & 32.6 & 3.45 \\
\hline DH-ase (mg INTF kg-1 $\mathrm{h}^{-1}$ ) & 47.3 & 3.87 & 1.72 & 0.38 & 6.18 & 3.09 \\
\hline Phosp (mg PNP kg ${ }^{-1} \mathrm{~h}^{-1}$ ) & 2931 & 633 & 3914 & 897 & 789 & 123 \\
\hline B-glu (mg PNP kg-1 $\mathrm{h}^{-1}$ ) & 316 & 245 & 144 & 94.9 & 37.1 & 13.5 \\
\hline Ure $\left(\mathrm{mg} \mathrm{NH}{ }_{3} \mathrm{~kg}^{-1} \mathrm{~h}^{-1}\right)$ & 203 & 22.4 & 20.4 & 11.0 & 7.31 & 1.00 \\
\hline $\mathrm{BAA}\left(\mathrm{mg} \mathrm{NH} \mathrm{kg}^{-1} \mathrm{~h}^{-1}\right)$ & 15.2 & 0.94 & 17.9 & 4.80 & 1.80 & 1.05 \\
\hline
\end{tabular}

DH-ase: dehydrogenase activity; Phosp: phosphatase activity; $\beta$-glu: $\beta$-glucosidase; Ure: urease; BAA: BAA-protease.

\subsection{Soil sampling and analytical methods}

Four soil samples from the surface layer $(0-20 \mathrm{~cm})$ were randomly taken from each plot to make a composite sample per plot, eight months after the last soil amendment. Samples were air-dried and ground to $0.5 \mathrm{~mm}$. Wet subsamples were stored until analysis at $4^{\circ} \mathrm{C}$ for biochemical assays. Soil $\mathrm{pH}$ was determined in the saturated soil extract and electrical conductivity (EC) in the $1: 5$ soil/water extract. Kjeldahl- $N$, available $P$ and available $K$ were determined by the methods described by Hesse [11].

The total organic carbon content (TOC) was determined by oxidation with potassium dichromate oxidation and titration with ferrous ammonium sulphate [12]. To determine total extractable carbon (TEC), soil samples were extracted with $0.1 \mathrm{M}$ sodium pyrophosphate and $0.1 \mathrm{M}$ sodium hydroxide. The supernatant was acidified to $\mathrm{pH} 2$ with $\mathrm{HCl}$ and let stand $24 \mathrm{~h}$ at room temperature. To separate fulvic acids (FA) from humic acids (HA), the solution was centrifuged and the precipitate containing HA dissolved with sodium hydroxide [13]. The TEC 
and the carbon of the humic extract (HAC) were determined by the method of Walkley and Black [12].

Available $\mathrm{Fe}, \mathrm{Mn}, \mathrm{Cu}, \mathrm{Zn}, \mathrm{Cd}, \mathrm{Co}, \mathrm{Ni}$ and $\mathrm{Pb}$ were extracted with a mixture of $0.005 \mathrm{M}$ DTPA (diethylenetriaminepentaacetic acid), $0.01 \mathrm{M} \mathrm{CaCl}_{2}$ and triethanolamin $0.1 \mathrm{M} \mathrm{[14]}$ and measured by ICP-OES.

Dehydrogenase (DH-ase) activity was measured following the method proposed by Trevors [15] and modified by García et al. [16], using INT (2-p-iodophenyl 3-p-nitrophenyl-5phenyltetrazolium chloride) as electron acceptor. Phosphatase (Phosp) and $\beta$-glucosidase ( $\beta$ glu) activities were determined according to Tabatabai [17] using $p$-nitrophenylphosphatase and $p$-nitrophenyl- $\beta$-D-glucopyranoside as substrates for Phosp and $\beta$-glu, respectively. Urease (Ure) and BAA-protease (BAA) activities were measured according to Nannipieri et al. [18] using urea and $\mathrm{N}$ - $\alpha$-benzoyl-L-argininamide (BAA) as substrates for urease and BAA-protease, respectively.

\subsection{Statistical methods}

The results were analyzed by ANOVA, considering the treatment as the independent variable. The means were separated by Tukey's test, considering a significance level of $p<0.05$ throughout the study. A correlation matrix was calculated with the values of organic carbon, heavy metals and enzyme activities. The significance levels of the correlation matrix $(p<0.01$ and $p<0.05$ ) are based on the Pearson coefficients.

\section{RESULTS AND DISCUSSION}

\subsection{Soil organic carbon contents}

Soil organic carbon contents (TOC, TEC and HAC) after 3 years of treatment are reported in Figure 1.

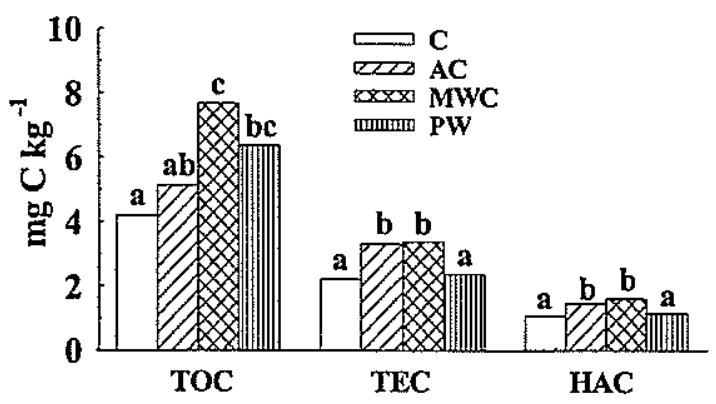

Figure 1. Organic carbon content (TOC, TEC and HAC) in the soils after 3 years of treatment. Values with the same letter are not significantly different $(p<0.05)$.

In general, the addition of the organic amendments had a noticeable effect on soil organic carbon contents. The TOC values in MWC- and PW-treated soils increased significantly when compared with the control soil. However, the dose of $\mathrm{AC}$ applied was not high enough to cause a significant increase of TOC. On the other hand, MWC and AC treatments increased 
significantly in soil humic fractions (TEC and HAC) when compared with the control soil (Figure 1). These materials (MWC and $\mathrm{AC}$ ) are rich in humic and fulvic compounds because during the composting process part of their organic matter was humified. On the contrary, PW is a fresh material with a low level of humified compounds. Therefore, its application did not increase the content of humic substances in the soil.

\subsection{Enzymatic activities}

Enzymatic activities were evaluated through some specific enzymes: an oxidoreductase (dehydrogenase) and four hydrolases (phosphatase, B-glucosidase, urease and BAA-protease).

Soil dehydrogenase activity reflects the total range of oxidative activity of soil microflora and consequently may be a good indicator of microbiological activity in the soil [19]. Dehydrogenase activity in the soil treated with both MWC and PW increased significantly when compared with the control soil (Figure 2), despite that dehydrogenase activity was low in those materials (Table 2). On the contrary, the relatively high value of dehydrogenase activity in $\mathrm{AC}$ did not increase the dehydrogenase activity in the soil amended with $\mathrm{AC}$ (Figure 2). These results suggest that the increase of the dehydrogenase activity in soils amended with organic residues is likely due to the stimulation of microbial activity rather than to the direct addition of the enzyme from the organic sources [2].

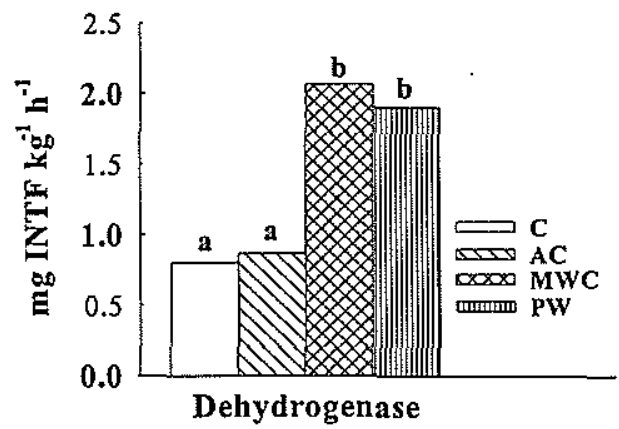

Figure 2. Dehydrogenase activity in the soils after 3 years of treatment. Values with the same letter are not significantly different $(p<0.05)$. (INTF: Iodonitrotetra zolium formazan).

Phosphatase and $B$-glucosidase activities are involved in the $\mathrm{P}$ and $\mathrm{C}$ cycles, respectively, and play an important role in the hydrolytic processes that take place during organic matter breakdown [20]. Phosphatase activity increased in the soils treated with both MWC and PW, although differences between treatments were only significant for soil treated with MWC (Figure 3), which also showed a significant increase of B-glucosidase activity.

Urease and BAA-protease activities, the other two hydrolytic enzymes studied, are involved in the last stages of organic $\mathrm{N}$ compound degradation by hydrolyzing $\mathrm{C}-\mathrm{N}$ bonds of amide and urea, respectively. Urease activity in soil greatly increased upon the application of the organic residues. The effect was more noticeable in MWC and PW treatments (Figure 4). BAAprotease activity also increased in soils treated with organic residues, although the differences 
with the control soil were only statistically significant in the soil amended with MWC. Beside the positive effect caused by the application of organic matter, the ureic- $\mathrm{N}$ applied to these soils could also contribute to the increase of the urease activity.

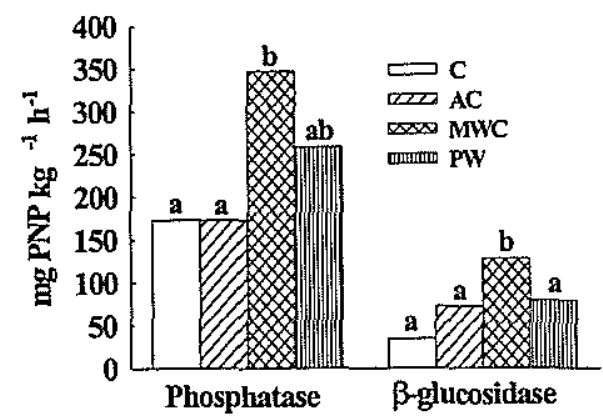

Figure 3. Phosphatase and $\beta$-glucosidase activities in the soils after 3 years of treatment. Values with the same letter are not significantly different $(p<0.05)$. (PNP: $p$-nitrophenol).

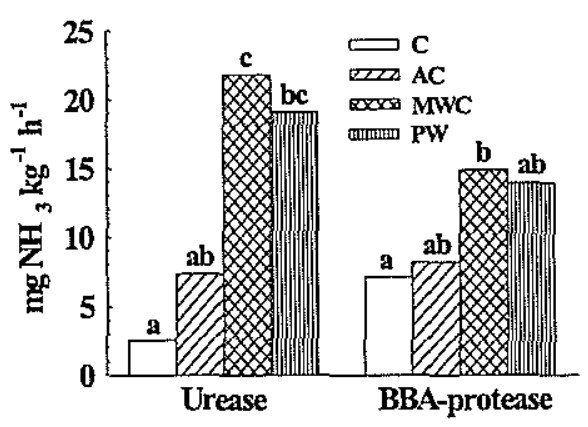

Figure 4. Urease and BAA-protease activities in the soils after 3 years of treatment. Values with the same letter are not significantly different $(p<0.05)$.

\subsection{Correlation between organic matter and enzyme activities}

Significant positive correlation between enzymatic activities and total organic carbon was found for all the treatments (Table 3), indicating the activation of soil microorganisms by the addition of the organic amendments [21,22]. Organic residues added to soil promote microbial and soil enzyme activities [23]. Moreover, high correlations were found between the five enzyme activities themselves. These correlations also suggest that although each individual enzyme depends on specific substrates and takes part in specific reactions, the simultaneous measurement of different enzyme activities in soil might be a valid tool for estimating the overall soil microbiological activity and the response to management practices [24]. It is also interesting to note that $\beta$-glucosidase, which is related to the $\mathrm{C}$ cycle, was the only enzyme that was positively correlated with the content of soil humic substances.

Table 3

Correlation coefficients between enzyme activities and total organic carbon (TOC)

\begin{tabular}{|c|c|c|c|c|c|c|c|c|}
\hline & TOC & TEC & HAC & DH-ase & Phosp & $\beta$-glu & Ure & $\overline{\mathrm{BAA}}$ \\
\hline TOC & & $0.400^{*}$ & $0.436^{*}$ & $0.864 * *$ & $0.705^{* *}$ & $0.602^{* *}$ & $0.872^{* *}$ & $0.681 * *$ \\
\hline TEC & & & $0.350^{*}$ & 0.236 & 0.293 & $0.531^{* *}$ & 0.265 & 0.283 \\
\hline HAC & & & & 0.342 & 0.332 & $0.362^{*}$ & 0.320 & 0.187 \\
\hline DH-ase & & & & & $0.658^{* *}$ & $0.450^{* *}$ & $0.872 * *$ & $0.670^{* *}$ \\
\hline Phosp & & & & & & $0.574^{* *}$ & $0.620^{* *}$ & $0.669^{* *}$ \\
\hline$\beta$-glu & & & & & & & $0.392^{*}$ & $0.472^{* *}$ \\
\hline Ure & & & & & & & & $0.721 * *$ \\
\hline BAA & & & & & & & & \\
\hline
\end{tabular}

* Significant at the 0.05 level. ** Significant at the 0.01 level.

DH-ase: dehydrogenase activity; Phosp: phosphatase activity; $\beta$-glu: $\beta$-glucosidase; Ure: urease; BAA: BAA-protease. 
Figure 5 shows the plot of the discriminant analysis useful to build a predictive model of each soil sample based on observed chemical and biochemical properties. The procedure generated, in this case, two canonical discriminant functions (F1 and F2) based on linear contributions of the variables (TOC, TEC, HAC, DH-ase, Phosp, $\beta$-glu, Ure, and BAA). These functions explain $98.6 \%$ of the variance between treatments (Table 4 ).

Through this analysis, it was observed that $\mathrm{F} 1$ is correlated with $\mathrm{DH}$-ase, TOC and BAA (Table 4). This function clearly separates treatments $\mathrm{C}$ and $\mathrm{AC}$ from $\mathrm{PW}$ and $\mathrm{MWC}$ and underlines the effect of the higher doses of organic matter applied with MWC and PW during the three years of study. On the other hand, F2, which is correlated with humic substances (TEC and $\mathrm{HAC}$ ) and $\beta$-glu (Table 4), separates treatments $\mathrm{C}$ and $\mathrm{PW}$ from $\mathrm{AC}$ and $\mathrm{MWC}$. This function shows the difference of the effect of composted (AC and MWC) and fresh residues (PW) on soil properties.

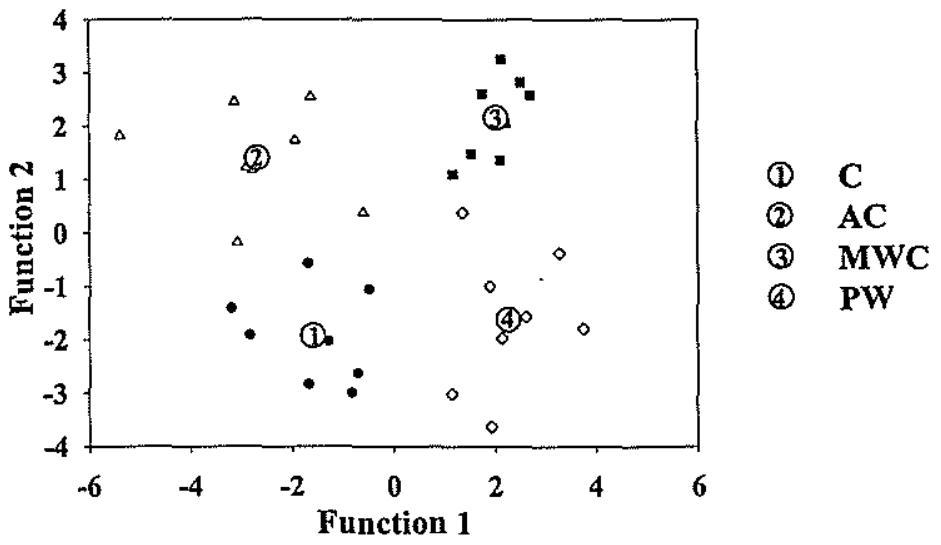

Figure 5. Discriminant analysis of some soil properties. Big circles are group centroids.

Table 4

Correlations between each variable and any discriminant function

\begin{tabular}{lll} 
& Function 1 & Function 2 \\
\cline { 2 - 3 } DH-ase & $0.659^{*}$ & 0.205 \\
TOC & $0.440^{*}$ & 0.357 \\
BBA & $0.298^{*}$ & 0.111 \\
TEC & -0.027 & $0.644^{*}$ \\
HAC & 0.110 & $0.436^{*}$ \\
B-glu & 0.291 & $0.407^{*}$ \\
Phosp & 0.326 & 0.207 \\
Ure & 0.335 & 0.165 \\
\hline \% of variance & 58.4 & 40.2 \\
\% of variance & 58.4 & 98.6 \\
\hline
\end{tabular}

* Largest absolute correlation. 
The amount of organic matter added had a great influence on dehydrogenase, which is considered a good indicator of microbial activity in the soil. However, the nature of the organic matter added (composted or fresh material) had a clear influence on the quality of the soil organic matter and consequently on $\beta$-glucosidase, which is closely related to the $\mathrm{C}$ cycle.

\subsection{Soil heavy metal contents}

Generally, at the end of the experiment, available heavy metal contents were higher in soils treated with PW and MWC than in soils of the other treatments (Table 5). The highest mean values of available heavy metal were found in the soil treated with PW. However, high values of available soil heavy metals were not only due to the high contents of heavy metals in PW and MWC but also to the higher doses of these amendments applied to the soil.

Although several studies showed that heavy metals can inhibit soil enzymatic activities [25, $26]$, in the present study the increase of heavy metal availability did not affect negatively enzymatic activities. On the contrary, soils amended with the residues richest in heavy metals (MWC and PW) had the highest values of enzymatic activities. Therefore, the positive effect of the organic matter could mask the possible enzyme inhibition caused by the increase of heavy metals in soil. Similar results were found by Giusquiani et al. [27] in soils treated with composted municipal waste. Moreover, negative correlations were not found between enzymatic activities and available heavy metals in soils (data not show).

\section{Table 5}

Available (DTPA) heavy metal contents of the soil after 3 years of treatment

\begin{tabular}{|c|c|c|c|c|c|c|c|c|}
\hline \multirow{3}{*}{$\frac{\text { Available-Metals }}{\mathrm{Fe}\left(\mathrm{mg} \mathrm{kg}^{-1}\right)}$} & \multicolumn{8}{|c|}{ Treatments } \\
\hline & \multicolumn{2}{|c|}{$\mathrm{C}$} & \multicolumn{2}{|c|}{$\mathrm{AC}$} & \multicolumn{2}{|c|}{ MWC } & \multicolumn{2}{|c|}{ PW } \\
\hline & 17.2 & $\mathrm{a}$ & 19.2 & a & 28.6 & $\mathrm{~b}$ & 18.5 & $\mathrm{a}$ \\
\hline $\mathrm{Mn}\left(\mathrm{mg} \mathrm{kg}^{-1}\right)$ & 10.5 & a & 9.88 & a & 11.5 & a & 18.3 & $\mathrm{~b}$ \\
\hline $\mathrm{Cu}\left(\mathrm{mg} \mathrm{kg}^{-1}\right)$ & 4.56 & a & 4.34 & a & 7.22 & a & 15.1 & $\mathrm{~b}$ \\
\hline $\mathrm{Zn}\left(\mathrm{mg} \mathrm{kg}^{-1}\right)$ & 8.36 & $\mathrm{a}$ & 8.88 & a & 15.2 & $\mathrm{~b}$ & 24.2 & c \\
\hline $\mathrm{Cd}\left(\mathrm{mg} \mathrm{kg}^{-1}\right)$ & 0.04 & a & 0.04 & $\mathbf{a}$ & 0.04 & $\mathrm{a}$ & 0.14 & b \\
\hline $\mathrm{Co}\left(\mathrm{mg} \mathrm{kg}^{-1}\right)$ & 0.10 & a & 0.10 & $\mathrm{a}$ & 0.10 & $\mathrm{a}$ & 0.28 & $\mathrm{~b}$ \\
\hline $\mathrm{Ni}\left(\mathrm{mg} \mathrm{kg}^{-1}\right)$ & 0.26 & a & 0.34 & $a b$ & 0.44 & b & 0.42 & $\mathrm{~b}$ \\
\hline $\mathrm{Pb}\left(\mathrm{mg} \mathrm{kg}^{-1}\right)$ & 1.32 & $\mathrm{a}$ & 1.70 & $a$ & 3.22 & $\mathrm{~b}$ & 1.82 & $\mathrm{a}$ \\
\hline
\end{tabular}

Values followed by the same letter in the same row are not significantly different $p<0.05$ ).

\section{CONCLUSIONS}

Repeated application of organic amendments to a sandy soil had a positive effect on soil organic matter content and soil enzymatic activities. In general, among treatments, municipal solid waste compost caused the higher positive effect on the soil properties. Moreover, a high positive correlation between soil organic carbon and soil enzymatic activities was found. The discriminant analysis underlined the effect of the higher doses of organic matter applied and the effect of composted and fresh residues on soil properties.

The relatively high concentration of heavy metals in municipal solid waste compost and in paper waste caused moderate increases of heavy metal contents in soil but no inhibition of soil enzymatic activities associated to heavy metals contamination was observed. 
The use of these residues can contribute to enhance the level of organic matter and probably the fertility of the agricultural soils in SW Andalusia, which are particularly poor in organic matter. Additionally, this practice would be an effective way of recycling the residues and solving the problem of their disposal.

\section{REFERENCES}

1. Masciandaro, G., Ceccanti B., García, C., 1997. Soil agro-ecological management: fertirrigation and vermicompost treatments. Biores. Technol. 59, 199-206.

2. Martens, D.A., Johanson, J.B., Frankenberger, W.T., 1992. Production and persistence of soil enzyme with repeated addition of organic residues. Soil Sci. 153, 53-61.

3. Bellamy, K.L., Chong, C., 1995. Paper sludge utilization in agriculture and container nursery culture. J. Environ. Qual. 24, 1074-1083.

4. Giusquiani, P.L., Pagliai, M., Gigliotti, G., Businelli, D., Benetti, A., 1995. Urban waste composts: effects on physical, chemical and biochemical soil properties. J. Environ. Qual. 24, 175-182.

5. Barker, A.V., 1997. Composition and uses of compost. $I n$ : Rechling, J.E., Mackinnon, H.C. (Eds.), Agricultural Uses of By-products and Wastes. American Chemical Society, Washington DC, ACS Symposium Series N ${ }^{\circ} 668$, Vol. 10, pp. 140-162.

6. Entry, J.A., Wood, B.H., Edwards, J.H., Wood, C.W., 1997. Influence of organic byproducts and nitrogen source on chemical and microbiological status of an agricultural soil. Biol. Fertil. Soils. 24, 196-204.

7. Pascual, J.A., García, C., Hernández, T., Ayuso, M., 1997. Changes in the microbial activity of an arid soil amended with urban organic wastes. Biol. Fertil. Soils 24, 429-434.

8. Salam, A.K., Desvia, Y., Sutanto, E., Syam, T., Nugroho S.G., Kimura, M., 1999. Activities of soil enzymes in different land-use systems in middle terrace areas of Lampung province, South Sumatra, Indonesia. Soil Sci. Plant. Nutr. 45 (1), 89-99.

9. Ceccanti, B., García, C., 1994. Coupled chemical and biochemical methodologies to characterize a composting process and the humic substances. In: Senesi, N., Miano, T. (Eds.), Proceedings $6^{\text {th }}$ Int. Meeting of Int. Humic Substances Society (IHSS), September 1993, Monopoli, Bari, Italy. Elsevier, Amsterdam, pp. 20-25.

10. Soil Survey Staff, 1996. Keys to Soil Taxonomy. US Department of Agriculture, Soil Conservation Service, Washington, DC.

11. Hesse, P.R., 1971. A Textbook of Soil Chemical Analysis. John Murray, London.

12. Walkley, A., Black, J.A., 1934. An examination of the Degtjareff method for determining soil organic matter and a proposed modification of the chromic acid titration method. Soil Sci. 37, 29-38.

13. Yeomans, J.C., Bremner, J.M., 1988. A rapid and precise method for routine determination of organic carbon in soil. Commun. Soil Sci. Plant Anal. 19, 1467-1476.

14. Lindsay, W.L., Norvell, W.A., 1978. Development of a DTPA soil test for zinc, iron, manganese and copper. Soil Sci. Soc. Am. J. 42, 421-428.

15. Trevors, J.T., 1984. Dehydrogenase activity in soil: a comparison between the INT and TTC assay. Soil Biol. Biochem. 16, 673-674.

16. García, C., Henández, T., Costa, F., Ceccanti, B., Masciandaro, G., 1993. The dehydrogenase activity of soils as an ecological marker in processes of perturbed system 
regeneration. In: Gallardo, J.F., (Ed.), XI Int. Symp. of Environmental Biogeochemistry, $11^{\text {th }}$, Salamanca, Spain. September 1993. CSIC, Salamanca, Spain, pp 89-100.

17. Tabatabai, M.A., 1994. Soil enzymes. In: Weaver, R.W., Angle, J.S., Bottomley, P.S. (Eds.), Methods of Soil Analysis. Part 2. Microbiological and Biochemical Properties. Soil Sci. Soc. Am. Madison, WI, pp. 778-833.

18. Nannipieri, P., Ceccanti, B., Cervelli, S., Matarese, E., 1980. Extraction of phosphatase, urease, protease, organic carbon and nitrogen from soil. Soil Sci. Soc. Am. J. 44, 10111016.

19. Skujins, J., 1976. Enzymes in soil. In: Mc Laren, A.D., Peterson, G.H. (Eds.), Soil Biochemistry. Vol. 1, Marcel Dekker, New York, pp. 371-414.

20. Müller, U., Wegener, P., 1988. Interaction of humic substances with biota. In: Frimmel F.H., Christman, R.F. (Eds.), Humic Substances and their Role in the Environment. John Wiley \& Sons, NY, pp. 179-192.

21. Dick, R.P., 1994. Soil enzyme activities as indicators of soil quality. Soil Sci. Soc. Am. J. 35, $107-124$.

22. Masciandaro, G., Ceccanti, B., García, C., 1997. Changes in soil biochemical and cracking properties induced by "living mulch systems". Can. J. Soil Sci. 77, 579-587.

23. Nannipieri, P., Muccini, L., Ciardi, C., 1983. Microbial biomass and enzyme activities: production and persistence. Soil Biol. Biochem. 15, 679-685.

24. García, C., Hemández, T., Costa, F., Ceccanti, B., 1994. Biochemical parameters in soils regenerated by the addition of organic wastes. Waste Mngt. Res. 12, 457-466.

25. Frankenberger, W.T., Johanson, J.B., Nelson, C.O. 1983. Urease activity in sewage sludgeamended soils. Soil Biol. Biochem. 15, 543-549.

26. Reddy, G.B., Faza, A., Bennet, R., Jr., 1987. Activity of enzymes in rhizosphere and nonrhizosphere soils amended with sludge. Soil Biol. Biochem. 19, 203-205.

27. Giusquiani, P.L., Gigliotti, G., Businelli, D., 1994. Long-term effects of heavy metals from composted municipal waste on some enzyme activities in a cultivated soil. Biol. Fertil. Soils $17,257-262$. 